\title{
İş Sağlığı ve Güvenliği Eğitimlerinde Tehlike Algılarının İncelenmesi
}

\author{
Effects of Occupational Health and Safety Trainings on Perception of Hazard
}

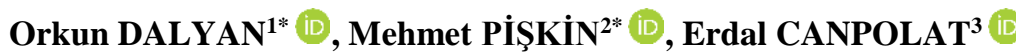

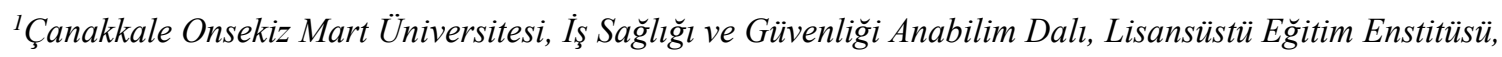 \\ 17020, Çanakkale, Türkiye \\ ${ }^{2}$ Çanakkale Onsekiz Mart Üniversitesi, Gıda İşleme Bölümü̈, Çanakkale Teknik Bilimler Meslek Yüksek Okulu, \\ 17020, Çanakkale, Türkiye \\ ${ }^{3}$ Fırat Üniversitesi, Fen Bilgisi Eğitimi Bölümü, Eğitim Fakültesi, 23119, Elâzlğ, Türkiye
}

$\ddot{\mathbf{O} z}$

İş sağllğı ve güvenliğine verilen önemin artmasıyla beraber iş güvenliği eğitimlerine verilen önemde artmıştır. İş kazalarının nedenleri hakkında yapılan birçok araştırmada, \% 80-90 oranında personellerin bireysel hatalarından kaynaklanan ve "güvensiz davranışlar" olarak adlandırılan durumlardan olduğu belirlenmiştir. Bahsi geçen bireysel hataların düzeltilmesi, iş kazası ve meslek hastalıklarının azaltılması için verimli iş sağlığı ve güvenliği eğitimleri, üzerinde durulması gereken önemli bir konudur. $\mathrm{Bu}$ çalı̧̧mada, iş güvenliği eğitimlerinin veriminin arttırılması amacıyla aynı sayıda ve benzer nitelikte 50'şer kişiden oluşan 3 çalışma grubuna farklı eğitimler uygulanmıştır. İlk gruba ofis ortamında işe özel eğitim, ikinci gruba çalışma ortamında işe özel işbaşı eğitimi, son gruba hem ofis ortamında işe özel eğitim hem de çalışma ortamında işe özel işbaşı eğitimi verilmiştir. Eğitimler sonrasında personellere çoktan seçmeli sınav yerine içeriğinde işe özgü tehlikeleri barındıran infografik çizim anketler uygulanarak personellerin tehlike algılarının farklı eğitimlere göre değişimi incelenmiştir. Araştırmada elde edilen verilerin istatistiksel analizinde SPSS 22.0 programından faydalanılmıştır. Analiz sonuçlarına göre, işe özgü eğitim ile işe özel işbaşı eğitiminin birlikte verildiği karma eğitimin, diğer iki eğitim türüne göre personellerin tehlike algısının arttırılmasında daha olumlu yönde etkili olduğu sonucuna ulaşılmıştır. Ayrıca, özel olarak eğitime tabi tutulması gereken gruplar demografik özelliklere göre sınıflandırılmıştır.

Anahtar Kelimeler: Güvenlik kültürü, İnfografik çizim, İşs sağlı̆ğ ve güvenliği eğitimleri, İş kazaları, Tehlike algısı.

*Bu çalışma Doç. Dr. Mehmet Pİ̧SKIN danışmanlığında Orkun DALYAN tarafından "İş Sağlı̆̆ı ve Güvenliği Eğitimlerinde Tehlike Algılarının İncelenmesi” başlıklı ve 665310 numaralı yüksek lisans tezinden türetilmiştir.

\begin{abstract}
With the increase in the importance given to occupational health and safety, the importance given to occupational safety training has increased. Many studies on the causes of occupational accidents indicate that there are cases called "unsafe behaviors" that are caused by the individual mistakes of the employees at a rate of $80-90 \%$. Efficient occupational health and safety training is an important issue that needs to be emphasized in order to correct the mentioned individual mistakes and reduce occupational accidents and diseases. In this study, in order to increase the efficiency of occupational safety trainings, trainings in different structure were applied to 3 working groups consisting of 50 people with the same number and similar quality. The first group was given job-specific training in the office, the second group was given job-specific toolbox training in the working area, the last group was given both job-specific and job-specific toolbox training. After the trainings, instead of multiple-choice exams, infographic drawing surveys containing job-specific hazards were applied to the personnel, and the change in the hazard perceptions of the personnel according to the trainings of different structures was determined. SPSS 22.0 program was used in the statistical analysis of the data obtained in the study. According to the results of the analysis, it was concluded that coeducation was more effective in increasing the danger perception of the personnel compared to the other two types of education. Also, the groups that need to be specially trained are classified according to their demographic characteristics.

Keywords: Safety Culture, Infographic Drawing, Occupational Health and Safety Trainings, Accident at Work, Hazard Perception.

\section{GíRiş}

Eğitim, bireyin duygusal, zihinsel ve bedensel olarak sahip olduğu yetenek, bilgi ve davranışlarının belirlenen bir amaç doğrultusunda geliştirilmesidir. Eğitim, sadece belirlenmiş bilgilerin alıcıya ulaştırılması ile sonuçlanan bir süreç değildir. Aksine içeriğinde politika, plan, program, uygulama, kontrol ve maddi imkanlar barındıran bir projedir [1]. Hazırlanacak projede; iş sağlığı ve güvenliğgi (ISG) mevzuatı, çalışma ortamına özgü tedbirler, yapılacak işe özgü tedbirler, sağlıklı çalışma ortamı ve hijyen konuları olmalıdır [2]. İSG eğitimlerinin uygulamalı olarak ve konularının rutin olarak verilmesi, personeller için davranış biçimine dönüşmesini sağlamaktadır [3].
\end{abstract}

Sorumlu yazar': Orkun DALYAN, Tel: +90 543799 14 05, e-posta: orkundalyan@outlook.com 
Personellere verilecek İSG eğitimleri, işyerindeki güvenlik kültürü oluşumunda ve personellerdeki güvenlik algısının yerleşmesinde en önemli basamağı oluşturmaktadır. İşyerlerinde personellerin güvenliğe ilişkin doğru tutum ve davranışlara sahip olmak için en çok başvurulan yöntemin ISG eğitimleri olduğu bilinmektedir. İSG eğitimi alan personellerin, İSG bilgileri ve işletmedeki riskler hakkında daha çok bilgilenmeleri ve daha güvenli çalışmalar yapmaları beklenen bir olgudur [4]. İşyerlerinde verilen İSG eğitimleri, personellerde İSG'ye yönelik olumlu davranış değişikliği sağlaması beklenmektedir [5]. Sağlıklı ve güvenli işyeri ortamı oluşturabilmek için ISG eğitimleri ile personellerin eğitilmesi, ISG konusundaki farkındalıklarının arttırılmasının önemi büyüktür [6]. Yapılacak İSG eğitimlerinin personellerde davranışsal değiş̧iklik ile sonuçlanması için öncelikle personellerin eğitimin önemine inanması gerekmektedir. Eğitimlerin önemli hedeflerinden biri de personeller de İSG bilincini oluşturabilmektir [7]. İSG eğitimlerinden beklenen amaç ise; iş kazası ve meslek hastalıklarını azaltmak, çalışma ortamında oluşabilecek tehlike ve riskleri bertaraf ederek sağlıklı ve güvenli bir işyeri temin etmektir. Materyal, ekipman ve çalışma şartları bakımında güvenli işyerleri oluşturulsa bile personellere güvenlik kültürü bilinci aşlanmazsa tehlikeler tamamen bertaraf edilememektedir. Güvenlik kültürü bilincinin oluşturulmasında İSG eğitimlerinin katkısı çok büyüktür [8]. Sonuçları verimli olan İSG eğitimleri personellerde güvenli davranış sergilemeyi ve işlerine özgü riskleri algılamalarını sağlayacaktır [9]. Bu sebeple farklı eğitim yöntemleri arasında hangisinin daha etkili sonuçlar verdiğinin araştırılması önemlidir.

\section{MATERYAL - YÖNTEM \\ 2.1. Araştırmanın Amacı}

$\mathrm{Bu}$ çalışmanın amacı personellere verilen farklı İSG eğitim yöntemleri (özel eğitim, işbaşı eğitimi, karma eğitim) sonucunda personellerdeki tehlike algısı değişim seviyesini ölçmektir.

Çalışma için 20/05/2021 tarih ve E-84026528050.01.04-2100073628 sayı ile Çanakkale Onsekiz Mart Üniversitesi Lisansüstü Eğitim Enstitüsü Etik Kurulu tarafından onay alınmıştır.

\subsection{Araştırma Yöntemi}

Personellere verilecek İSG eğitimlerinin tehlikeleri belirlemede algılarını ne derece etkileyeceği yönünde araştırma yapılan bu çalışmada, veri toplama yöntemi yüz yüze anket olarak belirlenmiștir. Personellere uygulanan anket formu Ek 1'de belirtilmiştir. Araştırma geneli ve anket hakkında bilgi verildikten sonra gönüllü onamları alınan personellere anket uygulaması yapılmış̧ır. Araştırma evrenini KınalıTekirdağ-Çanakkale-Savaştepe Otoyolu Projesi Malkara-Çanakkale (1915 Köprüsü Dâhil) Kesimi işinde ana yüklenici olarak görev alan Daelim-LimakSK E\&C-Yap1 Merkezi Joint Venture (DLSYJV) firması personellerinin tamamı $(\mathrm{N}=240)$ oluşturmaktadır. Araştırmanın örneklemini \%95 güven düzeyine göre 150 personel oluşturmuştur [10]. Katılımcıların seçimi konusunda araştırmacının herhangi bir etkisinin olmaması ve rastlantısal bir seçim yapılabilmesi için olasılıklı örnekleme yöntemlerinden basit rastgele örnekleme yöntemi kullanılmıştır [11]. 5 personel ve 5 çalışan temsilcisi ile pilot uygulama yapılmış olup ankette herhangi bir değişikliğe gerek olmadığı belirlenmiştir.

\subsection{Veri Toplama Araçları}

$\mathrm{Bu}$ çalışmada, personellerin tehlike algı değişimlerinin tespiti amaciyla içeriğinde işe özgü tehlikeler barındıran infografik çizimler oluşturulmuştur. 2 bölümden oluşan anket formu ve infografik çizimlerin tasarımı araştırmacılar tarafından hazırlanmıştır.

Anketin ilk kısmında katılımcıların demografik özelliklerini (cinsiyet, medeni durum, yaş, mesleki tecrübe ve eğitim düzeyi) tespit etmek amaciyla 5 adet soru bulunmaktadır. İkinci kısımda ise Şekil 1 ve 2'de yer alan infografik çizimlerden tespit edilen tehlikelerin belirtildiği alanlar bulunmaktadır.

Verilen eğitimler öncesi personellere uygulanan infografik çizim Şekil 1'de gösterilmiştir. Daha sonra personellere farklı yöntemler ile eğitimler verilmiş̧tir. Verilen eğitimlerin konusu, firma risk değerlendirmesi ve İSG kurul kararları neticesinde saptanmış ve Tablo 1 'de gösterilmiştir. Tablo 1'de belirtilen konuları içeren farklı eğitim yöntemleri sonrası personellere uygulanan infografik çizim Şekil 2'de gösterilmiş̧ir.

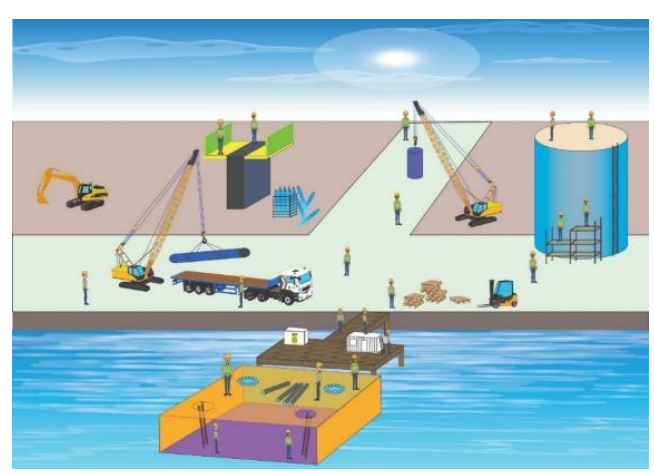

Şekil 1. Eğitimler öncesi personellere uygulanan infografik çizim

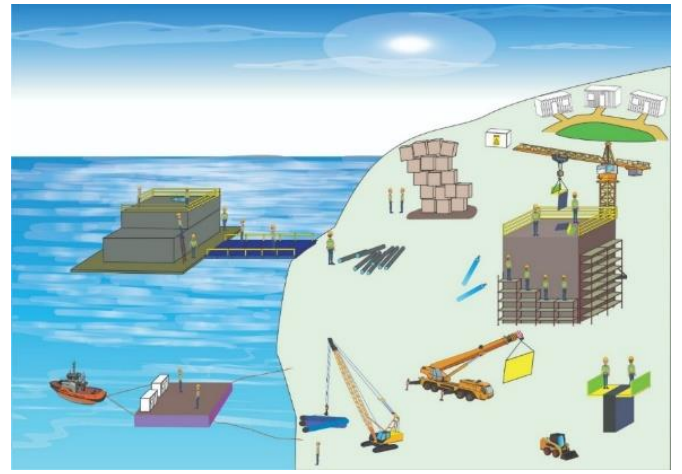

Şekil 2. Eğitimler sonrası personellere uygulanan infografik çizim 
Tablo 1. Eğitim konusu olarak belirlenen tehlike listesi

\begin{tabular}{|c|c|c|}
\hline $\begin{array}{l}\text { Sira } \\
\text { No }\end{array}$ & $\begin{array}{l}\text { Tehlikenin } \\
\text { çalışma kapsamı }\end{array}$ & Tespit edilmesi beklenen tehlike \\
\hline 1 & $\begin{array}{l}\text { Kapalı alan } \\
\text { çalışması }\end{array}$ & $\begin{array}{l}\text { Kapalı alan havalandırması yok, kapalı alan girişi sınırlandırılmamış, menhol } \\
\text { kapakları açı bırakılmış, gözcü personel yok, acil kurtarma üçgeni yok }\end{array}$ \\
\hline 2 & $\begin{array}{l}\text { Sapanlama } \\
\text { çalışması }\end{array}$ & $\begin{array}{l}\text { Farklı boyutlardaki malzemelerin birlikte bağlanması, uygun olmayan sapanlama } \\
\text { yöntemi, uygun olmayan sapan çeşidi (bez sapan, çelik sapan vb.) }\end{array}$ \\
\hline 3 & $\begin{array}{l}\text { Temizlik, tertip ve } \\
\text { düzen }\end{array}$ & $\begin{array}{l}\text { Zeminde bulunan dağınık malzemelere basarak takılıp-düşmeler, malzemelerin } \\
\text { yuvarlanması }\end{array}$ \\
\hline 4 & $\begin{array}{l}\text { Seyyar merdivenle } \\
\text { çalışma }\end{array}$ & Seyyar merdivenden yana sarkarak çalışmak, kaymaz tabanlık eksikliği \\
\hline 5 & $\begin{array}{l}\text { Kaldirma } \\
\text { operasyonu }\end{array}$ & $\begin{array}{l}\text { Kılavuz halat kullanımı yok, kaldırma operasyonu yapılan alan sınırlandırması } \\
\text { yok, işaretçi-sapancı personel yok }\end{array}$ \\
\hline 6 & Güvenli istifleme & Düzensiz istiflenen malzemelerin devrilme ihtimali \\
\hline 7 & $\begin{array}{l}\text { Denizde güvenli } \\
\text { çalışma }\end{array}$ & $\begin{array}{l}\text { Deniz üzeri çalışmalarda personellerde can yeleği eksikliği, deniz üzeri } \\
\text { platformda can simidi yok }\end{array}$ \\
\hline 8 & $\begin{array}{l}\text { İskele kurulum- } \\
\text { söküm }\end{array}$ & $\begin{array}{l}\text { İskele bileşenlerinin eksik olması (çapraz bağlantılar, korkuluk, süpürgelik vb.), } \\
\text { iskele kurulumu yapılan alan sınırlandırılmaması }\end{array}$ \\
\hline 9 & Yüksekte çalışma & $\begin{array}{l}\text { Yüksekte korkuluk ile kapatılmamış alan, yaşam hattı eksikliği, emniyet kemersiz } \\
\text { personeller, dikey ulaşım merdiveninde düşüş durdurucu sistemin olmaması }\end{array}$ \\
\hline 10 & $\begin{array}{l}\text { Basınçlı tüplerle } \\
\text { çalışma }\end{array}$ & $\begin{array}{l}\text { Tüplerin fiziksel etmenlerden etkilenmesi (güneş, yağmur vb.), tüplerin yatık } \\
\text { pozisyonda bırakılması ve kapalı bölmede depolanmaması }\end{array}$ \\
\hline
\end{tabular}

\subsection{Araştırma Sınırlılıkları}

Araştırmada kullanılan anket DLSYJV firmasının köprü kapsamında görevli personellerine uygulanmış olup araştırma bu personellerin görüşleri ile sınırlı tutulmuştur.

\subsection{Veri Analizi}

Personellere uygulanan infografik çizim anketlerde tespit edebildikleri her tehlike 1 puan olarak kayıt altına alınmış, yanlış ya da cevaplanmayan tehlikelere puan verilmemiştir. Ankette elde edilen ham veriler SPSS 22.0 bilgisayar destekli programı kullanılarak analiz edilmiştir. Anket ölçeğinin Cronbach Alpha güvenirlik katsayısı $\alpha=0.717$ gibi güvenilir sayılan bir değer bulunmuştur. Cronbach Alpha genellikle 0 ve +1 aralığında bir değer alır. Bu değer 1'e yaklaştıkça güvenirliği artar. Cronbach Alpha değeri; 0.00 ile 0.40 arasında güvenilir olmadığ $1,0.40$ ile 0.60 arasında düşük derecede güvenilir, 0.60 ile 0.90 arasında oldukça güvenilir, 0.90 ile 1.00 arasında yüksek derecede güvenilir olduğu ifade edilir [12].

Veri setlerinin normal dağılımı Kolmogorov-Smirnov testi ile kontrol edilmiş ve parametrik testlerden iki seviyeli değişkeni olan ifadeler için Bağımsız Değişken t Testi (Independent Sample t Test), ikiden fazla seviyeli değişkeni olan ifadeler için Tek Yönlü Varyans Analizi (One-Way Anova) kullanılmıştır [13]. Tek yönlü varyans analizi sonucunda anlamlı farklılığın yönü ve derecesini belirlemek amaciyla çoklu karşılaştırma testleri (Post Hoc) uygulanmıştır. Çoklu karşılaştırma testlerinin seçiminde karşılaştırılacak grup sayıları ile örneklem ve varyans eşitliği kriterleri değerlendirilerek karar verilmiştir [14]. Bağımsız değişkenin bağımlı değişken üzerindeki etki büyüklüğünü belirlemek amacıyla bağımsız değişken $t$ testinde Cohen d (d) etki büyüklügüü kat sayısı, tek yönlü varyans analizinde ise eta-kare ( $\eta 2)$ etki büyüklüğü katsayısı hesaplanmıştır. Cohen d etki büyüklüğü; 0.2 küçük, 0.5 orta ve 0.8 büyük etki olarak yorumlanmıştır [15]. Eta-kare etki büyüklüğü; 0.01 küçük, 0.06 orta ve 0.14 büyük etki olarak yorumlanmıştır [16]. Elde edilen bulgular \%95 güven aralığında, \%5 anlamlılık düzeyinde değerlendirilmiştir [17].

\section{BULGULAR VE TARTIŞMA}

Tablo 2'ye göre, araştırmaya katılan grupların toplamının \%89.4'ü erkek, \%10.6'si kadındır. Katılımciların medeni durumu \%52'si evli, \%48'i bekar olmak üzere eşite yakın dağılmıştır. Personellerin yaş dağılımı incelendiğinde en fazla katılımcının 26-40 yaş aralığında (\%58.7) olduğu, en az katılımcının ise 50 yaş üzeri kategorisinde $(\% 10.7)$ olduğu tespit edilmiştir. Sektörün çoğunluğunu hem tecrübeli hem de 
genç tabir edilebilecek yaş grubunun oluşturduğu belirlenmiştir. Katılımcıların büyük çoğunluğu ilköğretim (\%25.3) ve lise (\%37.3) mezunlarından oluşmaktadır. Okur-yazar ve lisansüstü kategorisinde eğitim düzeyine sahip katılımcı bulunmamıştır. Katılımcılar mesleki tecrübe süresi açısından değerlendirildiğinde ise 5 yıldan fazla (\%62.8) süreli çalışanın çoğunlukta olduğu görülmektedir ki bu durum büyük çaplı projelerde işe alım sürecinde dikkate alınan önemli bir kriterdir.

Tablo 3'e göre, eğitim öncesi ve sonrası fark puanların cinsiyet değişkenine göre kadınların puan ortalaması $(\overline{\mathrm{X}}=3.37)$ ve erkelerin puan ortalamas $(\overline{\mathrm{X}}=2.36)$ arasında kadınların lehine pozitif yönde anlamlı bir farklılık olduğu belirlenmiştir $(\mathrm{t}=2.73 ; \mathrm{p}<.05)$. Hesaplanan etki büyüklügü Cohen's d katsayısına göre orta derecede etkiye sahiptir $(\mathrm{d}=0.75)$. Eğitim öncesi ve sonrası fark puanlar medeni durum değişkeni ile karşılaştırıldığında, evli olanların puan ortalaması $(\overline{\mathrm{X}}=2.37)$ ve bekâr olanların puan ortalaması $(\overline{\mathrm{X}}=2.58)^{\prime}$ 'dır. Yapılan bağımsız t-testine göre evli ile bekar personellerin test ortalamaları arasında istatistiksel düzeyde anlamlı bir farklılık yoktur ( $\mathrm{t}=$ $0.90 ; \mathrm{p}>.05)$.

Tablo 4'e göre, eğitim öncesi ve sonrası fark puanlar yaş değişkenine göre incelendiğinde en az iki çalışma grubu arasında istatistiksel olarak anlamlı bir fark belirlenmiștir $(\mathrm{F}=2.598 ; \mathrm{p}<.05)$. Anlamlı farkın 18-25 ile 41-50 yaş arasında 18-25 yaş lehine olduğu belirlenmiştir. Hesaplanan eta-kare etki büyüklüğü katsayısına göre, bu farklılı̆ıın varyansa orta derecede etki etmiştir $(\eta 2=.94)$. Eğitim öncesi ve sonrası fark puanlar eğitim düzeyi değişkenine göre incelendiğinde en az iki çalışma grubu arasında istatistiksel olarak anlamlı bir farkl1lık olduğu belirlenmiştir $(\mathrm{F}=2.640$; $\mathrm{p}<.05$ ). Anlamlı farkın ilköğretim ile ön lisans arasında ilköğretim lehine olduğu belirlenmiştir. Hesaplanan eta-kare etki büyüklüğü katsayısına göre, bu farklılığın varyansa küçük derecede etki ettiği söylenebilir $(\eta 2=.05)$. Eğitim öncesi ve sonrası fark puanlar mesleki tecrübe değişkenine göre incelendiğinde en az iki çalışma grubu arasında istatistiksel olarak anlamlı bir fark gözlenmiştir $(\mathrm{F}=6.647 ; \mathrm{p}<.05)$. Anlamlı farkın 1 yıldan az ile 1-3 yıl arasında 1 yıldan az lehine, 1 yıldan az ile 3-5 yil arasinda 1 yildan az lehine ve 1 yıldan az ile 5 yildan fazla arasında 1 yildan az lehine olduğu görülmüştür. Hesaplanan eta-kare etki büyüklügü̈ katsayısına göre, bu farklılığın varyansa büyük derecede etki ettiği söylenebilir $(\eta 2=.12)$.

Tablo 5'e göre, çalışma gruplarına ait eğitim öncesi ve sonrası ortalama puan farkları ile en az iki çalışma grubu arasında istatistiksel olarak anlamlı bir fark gözlenmiştir $(\mathrm{F}=8.01 ; \mathrm{p}<.05)$. Anlamlı farkın karma grubu ile eğitim grubu arasında karma grup lehine ve karma grubu ile toolbox grubu arasında karma grubu lehine olduğu görülmüştür. Hesaplanan eta-kare etki büyüklüğü katsayısına göre, karma grubu eğitiminin çalışma gruplarının puan farklarına ait varyansa orta derecede etki ettiği söylenebilir $(\eta 2=.09)$.

Açık maden işletmesinde görevli 96 personel ile 3 farklı eğitim metodunun uygulandığ 1 bir çalışmada, videolu eğitimin sınıf eğitimi ve uygulamalı eğitimden ortalama \%50 daha başarılı olduğunu raporlamıştır [18]. Bu çalışmada, işe özel eğitim sonrası tehlike tespit oranı $\% 20$, işe özel toolbox eğitimi sonrası tehlike tespit oranı $\% 24$ ve karma eğitim sonrası tehlike tespit oranı $\% 31$ artış göstermiştir. İSG eğitimlerinde görsel ve sözel eğitimlerin sonuçları incelenen bir çalışmada görsel sunum içeren eğitimin yalnızca sözel olarak verilen eğitime göre daha başarılı olduğu rapor edilmiştir [19]. İnteraktif öğretme yöntemlerinin İSG'ye yönelik bilgi ve davranışa etkisini araştıran bir çalışmada ise interaktif eğitim yönteminin klasik eğitim yöntemine göre pozitif yönde anlamlı farklılığı olduğu rapor edilmiştir [20].

İSG eğitimlerinin inşaat sektöründe personeller üzerinde etkisi ve iş kazası yaşayan personellerin profilini oluşturmayı hedefleyen bir araştırmada uygulanan ankete katılım sağlayan personellerin yarısı İSG eğitimlerinin uygulamalı olarak verilmesinin verimli olacağını beyan ettikleri ve ayrıca İSG eğitimi alan personellerin $\% 72$ 'si iş güvenliği kurallarına riayet ettiği, \%76'sı İSG'nin iş hayatı kalitesini doğrudan etkilediği rapor edilmiştir [2]. Bu çalışmada eğitimler öncesi ve sonrası fark puanlar demografik özellikler bakımından incelendiğinde, cinsiyet değişkeninde kadın, yaş değişkeninde 18-25 yaş aralığı, eğitim düzeyinde ilköğretim ve mesleki tecrübe değişkeninde 1 ylldan az tecrübeye sahip personellerin özel eğitim alması gereken gruplar olarak tespit edilmiştir. Yasal mevzuat gereği personellere verilmesi gereken ISG eğitimlerinin daha verimli şekilde uygulanabilmesi için personellerin demografik özelliklerini inceleyen bir araştırmada, personellerin yaş, bilgi, eğitim, tecrübe vb. bir çok özelliğinin değişkenlik gösterdiğini dolayısıyla eğitimlerin tek bir modelde verilmemesi gerektiği rapor edilmiştir [21]. Evsel katı atık toplama ve taşıma işkolunda çalışanların iş sağlığ 1 ve güvenliği koşullarının değerlendirilmesi amacıyla yapılan bir araştırma çalışmasında, uygulanan ankete katılım sağlayan personellerden işe başlamadan önce teknik eğitim alan personellerin, eğitim almayan personellere göre daha fazla yaralanma veya hastalanma yaşadıkları rapor edilmiştir [22]. 
Tablo 2. Katılımcıların demografik özelliklerinin frekans ve yüzdeleri

\begin{tabular}{|c|c|c|c|c|c|c|c|c|c|}
\hline & & \multicolumn{2}{|c|}{ Eğitim Grubu } & \multicolumn{2}{|c|}{ Toolbox Grubu } & \multicolumn{2}{|c|}{ Karma Grup } & \multicolumn{2}{|c|}{$\begin{array}{l}\text { Gruplar } \\
\text { Toplamı }\end{array}$} \\
\hline \multicolumn{2}{|c|}{ Demografik Özellikler } & $\mathrm{N}$ & $\%$ & $\mathrm{~N}$ & $\%$ & $\mathrm{~N}$ & $\%$ & $\mathrm{~N}$ & $\%$ \\
\hline \multirow{2}{*}{ Cinsiyet } & Kadın & 4 & 8 & 8 & 16 & 4 & 8 & 16 & 10.6 \\
\hline & Erkek & 46 & 92 & 42 & 84 & 46 & 92 & 134 & 89.4 \\
\hline \multirow{2}{*}{ Medeni Durumu } & Evli & 28 & 56 & 24 & 48 & 26 & 52 & 78 & 52 \\
\hline & Bekâr & 22 & 44 & 26 & 52 & 24 & 48 & 72 & 48 \\
\hline \multirow{4}{*}{ Yaş } & $18-25$ yaş aralığ & 4 & 8 & 8 & 16 & 10 & 20 & 22 & 14.6 \\
\hline & $26-40$ yaş aralığ 1 & 28 & 56 & 30 & 60 & 30 & 60 & 88 & 58,7 \\
\hline & $41-50$ yaş aralı̆̆ & 12 & 24 & 4 & 8 & 8 & 16 & 24 & 16 \\
\hline & 50 yaş ve üzeri & 6 & 12 & 8 & 16 & 2 & 4 & 16 & 10.7 \\
\hline \multirow{6}{*}{ Öğretim Düzeyi } & Okur-Yazar & 0 & 0 & 0 & 0 & 0 & 0 & 0 & 0 \\
\hline & İlköğretim & 16 & 32 & 12 & 24 & 10 & 20 & 38 & 25.3 \\
\hline & Lise & 12 & 24 & 16 & 32 & 28 & 56 & 56 & 37.3 \\
\hline & Ön Lisans & 10 & 20 & 8 & 16 & 6 & 12 & 24 & 16 \\
\hline & Lisans & 12 & 24 & 14 & 28 & 6 & 12 & 32 & 21.3 \\
\hline & Lisans Üstü & 0 & 0 & 0 & 0 & 0 & 0 & 0 & 0 \\
\hline \multirow{5}{*}{ Mesleki Tecrübe } & 1 yıldan az & 2 & 4 & 2 & 4 & 10 & 20 & 14 & 9.3 \\
\hline & $1-3$ y1l aralığ 1 & 8 & 16 & 12 & 24 & 6 & 12 & 26 & 17.3 \\
\hline & 3-5 yıl aralığ & 8 & 16 & 6 & 12 & 2 & 4 & 16 & 10.6 \\
\hline & 5 yıldan fazla & 32 & 64 & 30 & 60 & 32 & 64 & 94 & 62.8 \\
\hline & Toplam & 50 & 100 & 50 & 100 & 50 & 100 & 150 & 100 \\
\hline
\end{tabular}

N:Katılımcı sayısı, \%:Yüzde

Tablo 3. Eğitim öncesi ve sonrası fark puanların cinsiyet ve medeni durum değişkenlerine göre Bağımsız t-Testi sonuçları

\begin{tabular}{cccccc}
\hline Gruplar & $\mathrm{N}$ & $\overline{\mathrm{X}}$ & $\mathrm{Sd}$ & $\mathrm{t}$ & $\mathrm{p}$ \\
\hline Kadın & 16 & 3.37 & 1.25 & 2.73 & $.007^{*}$ \\
Erkek & 134 & 2.36 & 1.41 & & .366 \\
Evli & 78 & 2.37 & 1.41 & -.90 & .366 \\
Bekâr & 72 & 2.58 & 1.44 & &
\end{tabular}

Tablo 4. Eğitim öncesi ve sonrası fark puanların yaş, öğretim düzeyi ve mesleki tecrübe değişkenlerine göre Tek

\begin{tabular}{|c|c|c|c|c|c|c|c|}
\hline & $\begin{array}{l}\text { Varyansin } \\
\text { kaynağ1 }\end{array}$ & $\begin{array}{l}\text { Kareler } \\
\text { toplam1 }\end{array}$ & $\mathrm{Sd}$ & $\begin{array}{l}\text { Kareler } \\
\text { ortalamas1 }\end{array}$ & $\mathrm{F}$ & $\mathrm{p}$ & Anlamlı fark \\
\hline \multirow[b]{2}{*}{ Yaş } & Gruplar aras1 & 15.37 & 3 & 5.126 & \multirow[b]{2}{*}{2.598} & \multirow[b]{2}{*}{$.050^{*}$} & \multirow[b]{2}{*}{$18-25$ ile $41-50$ yaş aras 1} \\
\hline & Gruplar içi & 288.01 & 146 & 1.973 & & & \\
\hline \multirow{2}{*}{$\begin{array}{l}\text { Eğitim } \\
\text { Düzeyi }\end{array}$} & Gruplar arası & 15.61 & 3 & 5.20 & \multirow[b]{2}{*}{2.640} & \multirow[b]{2}{*}{$.050^{*}$} & \multirow[b]{2}{*}{ İlköğretim ile Ön Lisans } \\
\hline & Gruplar içi & 287.78 & 146 & 1.97 & & & \\
\hline \multirow{2}{*}{$\begin{array}{l}\text { Mesleki } \\
\text { Tecrübe }\end{array}$} & Gruplar arası & 36.46 & 3 & 12.15 & \multirow{2}{*}{6.647} & \multirow{2}{*}{$.000^{*}$} & \multirow{2}{*}{$\begin{array}{l}1 \text { y1ldan az ile } 1-3 \text { y1l aras } 1 \\
1 \text { yildan az ile } 3-5 \text { y1l aras } 1 \\
1 \text { y1ldan az ile } 5 \text { yildan fazla } \\
\text { aras } 1\end{array}$} \\
\hline & Gruplar içi & 266.93 & 146 & 1.82 & & & \\
\hline
\end{tabular}

$\mathrm{p}<.05^{*}, \mathrm{p}=.05$

Tablo 5. Çalışma grupları arasındaki Tek Yönlü Varyans analiz sonucu

\begin{tabular}{|c|c|c|c|c|c|c|c|}
\hline & Grup & $\mathrm{N}$ & $\bar{X}$ & Ss & $\mathrm{F}$ & $\mathrm{p}$ & Anlamlı Fark \\
\hline \multirow{3}{*}{$\begin{array}{l}\text { Çalışma gruplarına ait eğitim } \\
\text { öncesi ve sonrası arasındaki } \\
\text { fark puan }\end{array}$} & Eğitim Grubu & 50 & 1.98 & 1,25 & \multirow{3}{*}{8.01} & \multirow{3}{*}{$.000 *$} & \multirow{3}{*}{$\begin{array}{l}\text { Karma grup ile } \\
\text { eğitim grubu } \\
\text { Karma grup ile } \\
\text { toolbox grubu }\end{array}$} \\
\hline & Toolbox Grubu & 50 & 2.38 & 1,48 & & & \\
\hline & Karma Grubu & 50 & 3.06 & 1,34 & & & \\
\hline
\end{tabular}

$\mathrm{p}<.05^{*}, \mathrm{p}=.05$ 


\section{SONUÇ VE ÖNERILER}

$\mathrm{Bu}$ çalışmada, ISG eğitimlerinin verimini arttırmak amaciyla 150 personele 3 farklı eğitim modeli uygulanmıştır. Eğitimler sonrası içeriğinde işe özgü tehlikeleri barındıran infografik çizim anketleri uygulanarak personellerin tehlike algisindaki değişimi üzerine veriler elde edilmiştir.

Eğitimler öncesi ve sonrası fark puanları demografik özellikler bakımından incelenerek özel eğitim alması gereken gruplar tespit edilmiştir. İSG eğitimlerinde görsel materyallere öncelikli olarak yer verilmesi gerektiği sonucuna varılmıştır. Karma eğitim modeli ile personeller hem ofis ortamında detaylı eğitim almakta hem de çalışma alanında her vardiya başlangıcında bilgilendirilmektedir. Karma eğitim modeli ile personeller işyerindeki risklere karşı daha duyarlı hale gelerek tehlike algıları gelişeceği öngörülmektedir.

Eğitimden sonra yapılan çoktan seçmeli sınavda personeller eğitimden yeterli verimi almamış olsa bile sorulara ait şılardan birini işaretleme eğiliminde bulunabilmektedir. Bahsedilen durum sonucu eğitimin ölçülmesi ve değerlendirilmesi sağlıklı sonuçlar vermeyecektir. Bu sebeple infografik çizim anketi ile yapılan sınavın çoktan seçmeli sınav yaklaşımına göre daha tutarlı sonuçlara ulaştıracağı düşünülmektedir. Görsel materyaller ile eğitim ölçme ve değerlendirme yaklaşımı, İSG profesyonellerinin eğitimleri ile uyumlaştırılarak Cumhurbaşkanlığı 11. Kalkınma planı 576.5 maddesinde belirtilen hedeflere ulaşılmasına katkı sağlayacağı kanaatindeyiz.

\section{TEŞEKKÜR}

$\mathrm{Bu}$ çalışma Çanakkale Onsekiz Mart Üniversitesi Bilimsel Araştırma Projeleri Koordinasyon Birimi tarafından desteklenmiştir. Proje numarası: FYL2020-3180

\section{KAYNAKLAR}

[1] Yılmaz, F. (2007). Ülkemizde İSG eğitiminde model arayışı. $\dot{I}_{S}$ Sağllğ $ı$ ve Güvenliği Dergisi, 35, 30-35.

[2] Gürsoy, T. (2019). Çalışanların iş sağlığı ve güvenliği eğitimlerinin değerlendirilmesi. Yüksek Lisans Tezi, Süleyman Demirel Üniversitesi Fen Bilimleri Enstitüsü, Türkiye, s. 5-8.

[3] Demir, E., Ensari Özay, M., Uçan, R. ve Kayhan, H. (2021). İş doyumu ile iş güvenliği algısı arasındaki ilişki: İnşaat iş̧̧ileri örneği. International Journal of Advances in Engineering and Pure Sciences, 33(1), 58-63.

[4] Bahari, S. F. (2011). An investigation of safety training, safety climate and safety outcomes: A longitudinal study in a Malaysian manufacturing plant. Doktora Tezi, The University of Manchester, UK, s. 144.
[5] T.C. Çalışma ve Sosyal Güvenlik Bakanlığı. (2013). Çalışanların İş Sağlığı ve Güvenliği Eğitimlerinin Usul ve Esasları Hakkında Yönetmelik. Resmî Gazete Sayı:28648, 15/05/2013.

[6] Demirbaş Erkan, G. (2019). İş sağglı̆̆ ve güvenliği eğitimlerinin işveren ve çalışanlarda davranış değişikliği etkinliği. Yüksek Lisans Tezi, İstanbul Rumeli Üniversitesi Fen Bilimleri Enstitüsü, Türkiye, s. 14.

[7] Yıldırım, E. (2010). İşçi sağlığı ve iş güvenliğinde eğitimin rolü ve işgörenlerin iş̧i sağlığı ve iş güvenliği eğitimi konusundaki bilinç düzeylerini ölçmeye yönelik bir araştırma. Yüksek Lisans Tezi, İstanbul Üniversitesi Sosyal Bilimler Enstitüsü, Türkiye, s. 122.

[8] Dalyan, O. ve Pişkin, M. (2020). İşyerlerinde ramak kala bildirimlerinin iş kazalarına etkisi ve inşaat sektöründe uygulama. Çanakkale Onsekiz Mart Üniversitesi Fen Bilimleri Enstitüsü Dergisi, 6(1), 133-143.

[9] Yenisarı, B. (2017). Kamu çalışanlarının iş güvenliği eğitimi konusundaki bilinç düzeylerinin araştırılması. Yüksek Lisans Tezi, Çanakkale Onsekiz Mart Üniversitesi Fen Bilimleri Enstitüsü, Türkiye, s. 72.

[10] Krejcie, V. R. ve Morgan, W. D. (1970). Determining sample size for research activities. Educational and Psychological Measurement, 30, 607-610.

[11] Yıldız, S. (2011). Sosyal bilimlerde örnekleme sorunu: Nicel ve nitel paradigmalardan örnekleme kuramına bütüncül bir bakış. Kesit Akademi Dergisi, 3(11), 421-442.

[12] Tavşancıl, E. (2019). Tutumların Ölçülmesi ve SPSS ile Veri Analizi. Nobel Akademi Yayıncılık, Ankara.

[13] Eymen, E. (2007). SPSS 15.0 Veri Analiz Yöntemleri. İstatistik Merkezi, Ankara.

[14] Kayri, M. (2009). Araştırmalarda gruplar arası farkın belirlenmesine yönelik çoklu karşılaştırma (Post-Hoc) teknikleri. Fırat Üniversitesi Sosyal Bilimler Dergisi, 19(1), 5164.

[15] Kılıç, S. (2014). Etki büyüklüğü. Journal of Mood Disorders, 4(1), 44-46.

[16] Büyüköztürk, Ş., Çokluk, Ö. ve Köklü, N. (2006). Sosyal Bilimler için İstatistik. Pegem Akademi Yayıncilık, Ankara.

[17] Özdamar, K., Odabaşı, Y., Hoşcan, Y., Bir, A. A., Kırcaali-İftar, G., Özmen, A. ve Uzuner, Y. (1999). Sosyal Bilimlerde Araştırma Yöntemleri. Anadolu Üniversitesi Yayınları, Eskişehir.

[18] Kol, İ. ve Özbek, S. (2021). İş sağlığı ve güvenliği eğitim uygulamalarının karşılaştırılması. OHS Academy, 4(1), 1-14.

[19] Hışır, H. (2018). İş sağlı̆̆ı ve güvenliği eğitimlerinde görsel ve sözel eğitimin 
etkinliğinin karşılaştırılması. Yüksek Lisans Tezi, Üsküdar Üniversitesi Sağlık Bilimleri Enstitüsü, Türkiye, s. 34.

[20] Bahadırlığlu, M. (2019). İnteraktif öğrenme yöntemlerinin iş sağlığ 1 ve güvenliğine yönelik bilgi ve davranışa etkisi. Yüksek Lisans Tezi, İzmir Ekonomi Üniversitesi Lisansüstü Eğitim Enstitüsü, Türkiye, s. 64.

[21] Temel, B. A. (2015). Trabzon il merkezindeki şantiyelerde çalışan işçilerin profilleri ile iş sağlığı ve güvenliği hakkındaki bilgi düzeylerinin belirlenmesi. Yüksek Lisans Tezi, Karadeniz Teknik Üniversitesi Fen Bilimleri Enstitüsü, Türkiye, s. 69.

[22] Gökyay, O. ve Özer, L. (2020). Evsel katı atık toplama ve taşıma işkolunda çalışanların iş sağlığı ve güvenliği koşullarının değerlendirilmesi, Ankara-Yenimahalle örneği. International Journal of Advances in Engineering and Pure Sciences, 32(4), 413419. 